MaŁgorzata M. Ptak

ORCID 0000-0003-2619-3149

MirosŁaW J. ŚmiaŁeK

ORCID 0000-0002-3131-4163

Uniwersytet im. Adama Mickiewicza

$w$ Poznaniu

\title{
OSOBA NAUCZYCIELA W EDUKACYJNEJ I EDUKOWANEJ PRZESTRZENI PRZYWÓDZTWA. (CZY DLA NAUCZYCIELI „EDUKACYJNE LUSTRO PANDEMICZNE" MOŻE STAĆ SIĘ "OŚWIATOWYM FANTAZMATEM"?)
}

\begin{abstract}
Ptak Małgorzata M., Śmiałek Mirosław J., Osoba nauczyciela w edukacyjnej i edukowanej przestrzeni przywództwa. (Czy dla nauczycieli „edukacyjne lustro pandemiczne” może stać się "oświatowym fantazmatem"?) [A Teacher in an Educational and Educated Leadership Space. (Can an "Educational Pandemic Mirror" Become an "Educational Phantasm" for Teachers?)]. Studia Edukacyjne nr 57, 2020, Poznań 2020, pp. 177-189. Adam Mickiewicz University Press. ISSN 1233-6688. DOI: $10.14746 /$ se. 2020.57 .12
\end{abstract}

The world of social norms and values is constantly embedded in the teacher's actions and the educational theories they recognise, in their didactic end educational successes and failures, in professional adaptation and evaluation, in didacticism and educational inspiration, and in the case of a few, in educational leadership deprived of the external and personal world. In every dimension of the teacher's pedagogical activities there is a link between the acquired theoretical knowledge and the professional attitude. The pedagogical approximation into specific theories and pedagogical ideas is illustrated by the professional attitude of the teacher, interpersonal relations with students and the teaching staff. The knowledge of pedagogical paradigms, the realization of diverse ideas can be a factor in a teacher's pedagogical success, as there is no single theory, explaining and suitable for a specific school community in the educational space. Contemporary pedagogical theories, like never in the past, are becoming a creator of social mentality in multicultural environments. They are becoming a "civilizational hope" for the reduction of traditional "prescriptive-distributive" thinking, as well as subject-based, directive and authoritarian education, and educational impossibilism in schools. Contemporary pedagogical controversies around the relationship of education and leadership do not have antagonistic content, elements that are pedagogically and socially opposed. They interact with each other in various and multi-level ways in the space of humanistic pedagogy and human resource management, they are a pedagogical dualism in the sphere of descriptive and relational narrative, critical thinking, without space for academic logomachia. The growing interest in the teacher's autonomy, teacher's independence, the dimensions of the presence in 
the pedagogical community, and the pursuit of individual needs are issues of external educational affiliation. What educational and cultural dimension should constitute the pedagogical habitus of a modern teacher? From the content of many pedagogical publications, a conclusion emerges that in education, it is not the teachers who become the motivators of exceeding knowledge and skills for themselves, but the students who exceed their teachers. Such a confrontation of the two worlds: teachers, representing institutionalised education and students (more precisely: learners), having one common goal - mutual understanding, which already requires a change in the generation paradigm, methods of operation, education (students and teachers), modification of the education already acquired, transformation of the model of "becoming" a teacher (usually based on authority - still traditional) more effectively appealing to students and systematic use of the new technological solutions in the education process. Increasingly, many pedagogical ideas and theories are starting to signal the need to transpose the role of the teacher in the spectrum of expert-conceptual practitioner, which is based on the methods and techniques of learning, i.e. critical thinking.

Key words: teacher, educational theories, educational space, educational, leadership, interpersonal relations, pedagogical paradigm

Celem nauki nie jest otwieranie drzwi nieskończonej mądrości, lecz położenie kresu nieskończonym błędom.

Berthold Brecht

Wiedza - dzięki niej człowiek lepiej rozumie świat dziejący się zewnętrznie, rozumie i kształtuje jego znaczenia $\mathrm{w}$ wymiarze podmiotowym i przedmiotowym. Jest niezwykle istotna $\mathrm{w}$ pedagogice, dokładnie interpretującej treści kultury i dziedzictwa, mechanizmy wyobrażeniowe, jakim podlega ludzkie myślenie i działanie, w przygotowaniu młodego pokolenia do nowego odbioru rzeczywistości. Wiedza to najistotniejsze ze wszystkich znaczeń w przestrzeni edukacyjnej. Daje poczucie pewności siebie, kształtując motywacje i aspiracje zawodowe, ale przede wszystkim pomagając $w$ akomodacji do społecznych wzorów kulturowych. Edukacja, sama stanowiąc stale dokonujący się proces, niemający granicy ciągłości i bezruchu w zmienności, nieustannie wykorzystując wartości, umiejscawia w swojej przestrzeni osoby wychowawcy i wychowanka. To właśnie edukacyjna zmienność wiedzy, czasu, miejsca, wymiaru przestrzennego sprawia, że każdy nauczyciel i uczeń funkcjonują w strukturze pytań, wątpliwości, dociekań oraz ciekawości. Adekwatność podejmowanych działań nauczyciela i osiągane efekty edukacyjne w postaci progresu intelektualnego ucznia, leksykalnej genezy, wpisują się w łaciński rdzeń słowa „edukacja" - educare (wychowywać) i ex duco (wyprowadzać), stanowiąc o wielopokoleniowej misji społecznej doskonalenia otaczającej rzeczywistości lub jej inkluzji, coraz częściej multikuturowej, a także wirtualnej.

W każdym wymiarze pedagogicznych działań nauczyciela dokonuje się związek pomiędzy przyswojoną wiedzą teoretyczną a realizowaną postawą zawodową. Aproksymacja ${ }^{1}$ pedagogiczna w określone teorie i idee pedago-

\footnotetext{
${ }^{1}$ Aproksymacja - wzrastanie w normy, wartości, zasady poprzez fakt powinności.
} 
giczne jest obrazowana postawą zawodową nauczyciela, relacjami interpersonalnymi z uczniami i gronem pedagogicznym. W każdym środowisku edukacyjnym można odnaleźć aspekty współczesnych teorii pedagogicznych, wskazać nauczycieli realizujących określone aksjomaty wychowawcze i edukacyjne, bowiem współczesna przestrzeń edukacyjna to stale żywy "tygiel” wielowątkowych procesów opartych na cywilizacyjnej transformacji. Rok 2020 ukazal, w stopniu nieprzewidywalnym, skalę oświatowej zależności od normatywnego i deskryptywnego pojmowania kształcenia w paradygmacie deontycznym i przedmiotowym.

Szczęśliwy czas edukacyjny to taki, w którym jest nie tylko przyzwolenie, ale wręcz obecna u nauczycieli zdolność do krytycznego i twórczego namysłu, inkluzja dostrzegania i umiejętnego klasyfikowania społecznych sytuacji niejasnych, problematycznych i wielowarstwowych. Znajomość i wiedza paradygmatów teorii pedagogicznych, realizacja zróżnicowanych idei stanowić może o sukcesie pedagogicznym pracy nauczyciela, gdyż nie ma jednej teorii, wyjaśniającej i odpowiedniej dla określonej społeczności szkolnej i przestrzeni edukacyjnej. Współczesne teorie pedagogiczne, jak nigdy w przeszłości, stają się kreatorem społecznej mentalności $\mathrm{w}$ wielokulturowych środowiskach, stają się "cywilizacyjną nadzieją" na redukcję w placówkach szkolnych tradycyjnego myślenia typu „nakazowo-rozdzielczego", edukacji przedmiotowej, wychowania dyrektywnego, autorytarnego i imposybilizmu oświatowego.

Uwzględniając mnogość teorii i definicji, próbujących w możliwie precyzyjny sposób określić relacje nauczyciel - uczeń należy pamiętać, że dopiero od niedawna pedagogiczne postrzeganie edukacyjnych zobowiązań wychowawcy wobec wychowanka zaczęto ujmować zdaniem: podstawowy cel wychowania to integralność fizyczna, umysłowa, uczuciowa i etyczna każdego człowieka będącego twórca samego siebie. To także proces wyprowadzania dziecka ucznia - wychowanka ze stanu niższego do stanu wyższego, od stanu natury do stanu kultury ${ }^{2}, \mathrm{w}$ zgodzie z maksymą semper in altum (zawsze wzwyż). Czy zatem istnieje podmiotowy inwariant wychowawcy, który spełniałby tak zróżnicowane, wieloaspektowe potrzeby środowiska wychowawczego? Na pewno, wychowanie przez samodzielną pracę, działania poszukujące dla dzieci, edukacja polegająca na pracy według własnych sił i zindywidualizowanego czasu to pedagogiczny kierunkowskaz dla wyznaczanych celów dydaktycznych, edukacyjnych i opiekuńczych. Wychowanie w nich będzie „oznaczać pobudzanie i ukierunkowanie rozwoju osoby ludzkiej, (...) a samowychowanie pobudzanie i ukierunkowanie własnego rozwoju"3.

\footnotetext{
2 S. Kunowski, Podstawy wspótczesnej pedagogiki, Warszawa 1993.

3 S. Sławiński, Wychowywać do postuszeństwa, Warszawa 1994, s. 5.
} 
W tradycyjnym modelu wychowania, $\mathrm{z}$ tytułu dominacji władzy wychowawczej nieobecny był dialog, a we współczesnych modelach dialog i rolę władzy wychowawczej postrzega się marginalnie, sytuując je $w$ treściach pedagogicznej schedy, a przecież w każdym działaniu wychowawczym są to główne i wzajemnie uzupełniające się elementy. Współczesne pedagogiczne kontrowersje wokół relacji wychowanie - przywództwo nie posiadają w sobie treści antagonistycznych, elementów przeciwstawnych pedagogicznie i społecznie. Obydwa oddziałują na siebie wzajemnie różnymi i wielopoziomowymi sposobami w materii pedagogiki humanistycznej i zarządzania zasobami ludzkimi, są pedagogicznym dualizmem w sferze narracji deskryptywnej i relacyjnej, krytycznego myślenia, bez akademickiej logomachii.

Praktyka edukacyjna stanowi świat norm i wartości społecznych nieustannie wpisujących się w działania nauczyciela i osobiste teorie edukacyjne, w sukcesy i porażki wychowawcze, w adaptację i ewaluację zawodową, w dydaktyzm i inspirację edukacyjną, a u nielicznych w przywództwo edukacyjne pozbawione scjentycznego rozumienia świata zewnętrznego i osobistego.

W edukacji nie ma miejsca na radykalizm, instytucjonalny symetryzm ocenny placówek szkolnych, bowiem przestrzeń edukacyjna to stałość zmienności, to naprzemienność „zysków i strat”, zróżnicowanie, prawo nauczyciela do wolności wyboru poziomu i jakości nauczania oraz wychowania, prawa ucznia do wolnego wyboru szkoły. Środowisko uczenia się i społeczność szkolna także doświadcza uwarunkowań historycznych, zależności ekonomicznych i treści kulturowych, a współczesny nauczyciel w specyfikę metod i narzędzi edukacyjnych jest obowiązany wpisywać świadomość skutków procesów ogólnoświatowych: globalizacji, konsumeryzmu, a przede wszystkim nieustannej asymilacji w wielokulturowość.

Rosnące zainteresowanie autonomią nauczyciela, jego niezależnością, wymiarami obecności w pedagogicznej wspólnocie, dążeniami do realizacji indywidualnych potrzeb to zagadnienia uzewnętrznianej edukacyjnej afiliacji. Dlaczego jego spektrum rodzi więcej pytań niż wniosków? Kto i co „dzisiaj” decyduje o treści i wartościach granicznych w aspektach: szkolnym, edukacyjno-kulturowym i osobowościowo-kulturowym? Jaki wymiar edukacyjny i kulturowy powinien stanowić o pedagogicznym habitusie współczesnego nauczyciela? Dlaczego tak trudne jest nauczanie i wychowanie online oparte na podmiotowości? Z wielu publikacji pedagogicznych coraz częściej wyłania się wniosek, że w edukacji to nie nauczyciele stają się dla siebie motywatorami przekraczania wiedzy i umiejętności, ale uczniowie wykraczający przed swoich nauczycieli. Taka konfrontacja światów: nauczycieli reprezentujących zinstytucjonalizowaną edukację i uczniów (mówiąc precyzyjniej: osób uczących się) mających jeden wspólny cel - wzajemne zrozumienie, już teraz wymaga 
zmiany paradygmatu generacyjnego, metod działania, kształcenia (uczniów i nauczycieli), modyfikacji wykształcenia już zdobytego, transformacji modelu „stawania się” nauczycielem (najczęściej opartego na autorytecie - jeszcze tradycyjnym) efektywniej przemawiającego do uczniów oraz systematycznego korzystania z nowych rozwiązań technologicznych w procesie edukacji.

W połowie lat siedemdziesiątych XX wieku tylko pedagodzy bardzo szybko zdali sobie sprawę, że ograniczanie analizy procesów i procedur kształcenia jedynie do wewnętrznego funkcjonowania nauczyciela i do wiedzy o nim samym nie było pełnym obrazowaniem jego obecności w przestrzeni edukacyjnej, nie akcentowało wszystkich warunków wpływających na kształtowanie stawania się pedagogiem, było jedynie zbiurokratyzowaną aproksymacją oświatową!

Nie czas i miejsce na analizę, czy to teoria pedagogiczna determinuje praktykę nauczycielską, czy praktyka jest generatorem analiz teoretycznych dla pedeutologii. Pewne jest, że wzór osobowy nauczyciela, wielość postaw nauczycieli, dylematy roli zawodowej, dynamizmy zawodowego wypalenia nauczycieli, to odwieczna wątpliwość, co jest ważniejsze i podmiotowe - misja czy zawód? A to tylko nieliczne aksjomaty z tak bardzo niejednoznacznej roli nauczyciela. Właśnie obecność wielu teorii pedagogicznych sprawia, że nie ma jednoznacznej postawy, czy zawód nauczyciela należy ujmować historycznie czy komparatystycznie? Tożsamość nauczyciela jest realizowana w wymiarze transgresji kulturowej i stratyfikacji ekonomiczno-społecznej, wiedzy prywatnej i wewnętrznego programu aksjologicznego, roli wychowawcy i edukatora, nauczyciela w zespole klasowym i przywódcy dla grupy uczniowskiej, ale także outsidera i przedstawiciela dokonujących się zmian społeczno-edukacyjnych. Niezmiennie od wielu pokoleń najważniejszy i najcenniejszy jest osąd nauczyciela wydawany na podstawie tego, czego nauczył swoich uczniów.

Tożsamość nauczyciela zaczyna być budowana,

gdy ktoś zada pytanie. Bez pytań nauczyciel nie istnieje. Odpowiadać na pytania tak, by powiedzieć wystarczająco dużo, lecz nie za dużo, to trudna sztuka - sztuka znana nauczycielom ${ }^{4}$.

Jednostkowo może być warunkowana subiektywnym oraz obiektywnym postrzeganiem stereotypów i autostereotypów wynikających z istnienia w przestrzeni edukacyjnej zbiorowości oraz równowagi biopsychicznej ${ }^{5}$. Tożsamość nauczyciela i jego habitus budowany przez społeczne stereotypy do-

\footnotetext{
${ }^{4}$ J. Holt, Zamiast edukacji. Warunki do uczenia się przez działanie, przekł. D. Konowrocka, Kraków 2007, s. 1.

${ }^{5}$ K. Kwaśniewski, Tożsamość społeczna i kulturowa, Studia Socjologiczne, 1986, 3, s. 12.
} 
skonale obrazują: teoria osobowości autorytarnej T. Adorno, teoria społecznego odzwierciedlenia uprzedzeń A. Bandury, teoria tożsamości i kategoryzacji społecznej H. Tajfela i J. Turnera oraz teoria społeczno-poznawczego rozwoju uprzedzeń, dla których aplikacje „w zbiorze - tożsamość i identyfikacja” stanowią: podstawowy błąd atrybucji, tendencja samoobronny, egocentryzm, iluzja asymetrycznego wglądu, fenomen sprawiedliwego świata, zasada homogeniczności zewnętrza, błąd przypisywania cech, samospełniające się proroctwo i efekty: horoskopowy, projekcji, aureoli, grupy, ponadprzeciętności.

Tożsamość indywidualna stając się prawdziwym wyzwaniem dla filozofii, socjologii, psychologii, u pedagogów zapoczątkowała nowy nurt aberracji myślowej o nauczycielu i uczniu. Ch.H. Cooley analizując źródła i przebieg procesu zdobywania wiedzy o samym sobie sformułował koncepcję „lustrzanego odbicia”. Zgodnie z nią, nauczyciel najpełniejszą wiedzę o sobie samym zdobywa na podstawie relacji emocjonalnych, opinii i ocen od innych nauczycieli, uczniów, a także rodziców. O ile jeszcze kilka lat temu oczywisty był fakt, że to zespół klasowy dostosowywał się do metod i form nauczyciela, o tyle obecnie coraz częściej sytuacja jest odwrotna - to nauczyciel, analizując predyspozycje i aktywność intelektualną swoich uczniów, dostosuje odpowiednie środki dydaktyczne i wychowawcze do tak zdiagnozowanej klasy. W publikacjach pedagogicznych coraz częściej jest akcentowana edukacja i wychowanie dostrzegające osobę zróżnicowaną kulturowo, społecznie i ze zróżnicowaną wiedzą przedmiotową. Wiosna 2020 roku perfekcyjnie zweryfikowała podmiotowość i przedmiotowość edukacyjną nauczycielskiego "lustrzanego odbicia”. Jego klasyfikatorami stały się między innymi woluntaryzm ministerialny, wirtualny uczniowski vox populi, pandemiczny wymiar "odpadu szkolnego", celebryctwo metodyczne i emergencja dydaktyczna.

G.H. Mead jeszcze bardziej uzależnił budowanie indywidualnej tożsamości od społeczeństwa, głosząc, że jest ona jego odbiciem. Normy i wartości obecne $\mathrm{w}$ grupie społecznej są internalizowane poprzez identyfikację, stając się wyznacznikami tożsamości indywidualnej ${ }^{6}$. Interakcjoniści symboliczni proces ten nazwali uwewnętrznieniem zewnętrzności, a socjolodzy określili socjalizacją

(...) $\mathrm{w}$ „,z góry" przygotowaną tożsamość, która jest logiczna wówczas, gdy cechy społeczeństwa i kultury, w której dana osoba ludzka żyje, odpowiadają owej tożsamości. Tożsamość osoby ludzkiej jest wtedy „nagradzana” przez odnajdywanie swojego wizerunku (niczym w lustrze) w tysiącach fenomenów społecznych. Dziś nie jest to już możliwe. Rzeczywistość jest w znaczącym stopniu sfragmentaryzowana. Tysiące sprzecznych prawd rywalizuje w niej ze sobą o status jedynej prawdy, relatywizując siebie nieustannie. Tysiące sposobów (re)prezentacji ściga się o status obiektywności.

${ }^{6}$ E. Aronson, T.D. Wilson, R.M. Akert, Psychologia społeczna, Poznań 1997, rozdz. 6. 
Kanon i różnica, lokalne i globalne, intelektualne i afektywne, popularne i elitarne. Typowe dla przeszłości rozróżnienia i binaryzmy na naszych oczach „wyparowują"7

To pogląd, podejmujący problematykę, w jakim stopniu przestrzeń edukacyjna i edukowana są uspójnione z kształtowaniem postaci wychowawcy, nauczyciela, pedagoga? Która ze sfer jest dominująca, kiedy, dla kogo, jakie czynniki deontologii zawodowej mają na tę współzależność największe oddziaływanie? Czy kształcenie online w najbliższym czasie będzie sytuować się w sferze interioryzacji edukacyjnej, czy może wygeneruje tożsamość tak zwanej anomii pedagogicznej?

Teleologia pedeutologiczna zawiera w sobie treści wielu celów dydaktycznych i wychowawczych oraz etycznych roli zawodowej pedagoga. Roli społecznie szczególnej, bowiem obwarowanej wysokimi wymaganiami. Nauczyciel powinien być dobrym specjalistą $\mathrm{w}$ dziedzinie nauczanego przedmiotu, posiadać odpowiednie kompetencje socjologiczne, psychologiczne, etyczne, trafnie diagnozować społeczne relacje w klasie, przy zachowaniu zasad podmiotowości wobec uczniów. Wiele idei i teorii pedagogicznych coraz częściej zaczyna sygnalizować potrzebę transpozycji roli nauczyciela w spektrum ekspert - refleksyjny praktyk, którego podstawą metod i technik kształcenia jest tak zwane myślenie krytyczne.

Ta refleksyjność nauczyciela jest warunkowana genezą historyczną, bowiem grecki termin paideia oznacza czynienie ucznia „bardziej” człowiekiem, to jest postrzeganie go nie tylko $\mathrm{w}$ perspektywie ontologicznej (jakie uzdolnienia i możliwości wynikają z fizycznej kondycji ucznia?), ale również w perspektywie humanistycznej (kim może się stać?). Taki dualizm perspektyw edukacyjnych, ujmujący ucznia w wymiarze celów i wartości realizuje najważniejszą pedagogiczną schedę - poszukiwania odpowiedzi na pytania: kim jest uczeń? $\mathrm{w}$ wymiarze temporalnym z perspektywy empirycznej, aby przystosować go do świata, w którym żyje; kim staje się uczeń? w pryzmacie prakseologicznym, akceptując i asymilując wartości społeczne, oraz kim ma być uczeń? w perspektywie aksjologiczno-światopoglądowej. Aksjologia pedagogiczna także pyta: kim jest nauczyciel? sytuując odpowiedź w ocenie: wartością tego, czym jest, czyli prawdą; kim staje się nauczyciel? - wartością tego, czym się staje, czyli dobrem oraz kim ma być nauczyciel? - wartością tego, czym ma być, czyli pięknem. To najważniejsze filary stwarzania, stawania się i bycia nauczycielem, jako człowieka - osoby - przewodnika - przywódcy na gruncie pedagogiki materialistycznej, pragmatyzmu Marksa, a także pedagogiki egzystencjalnej i personalistycznej. Te pedagogiczne źródła to filary konstruowania tożsamości nauczyciela budującego siebie, jako Osobę, pyta-

${ }^{7}$ Z. Melosik, Kultura popularna jako czynnik socjalizacji, [w:] Pedagogika. Podręcznik akademic$k i$, tom 2, red. Z. Kwieciński, B. Śliwerski, Warszawa 2003, s. 69. 
jącego: co i kto stanowi o Jego wartości? Realizując Dobro, Piękno i Prawdę, a zatem wartości transcedentalne, czyli najwyższe, samoistne, absolutne. Nauczyciel kształtuje wychowawczą funkcję przestrzeni edukacyjnej ucznia w sferze procesów:

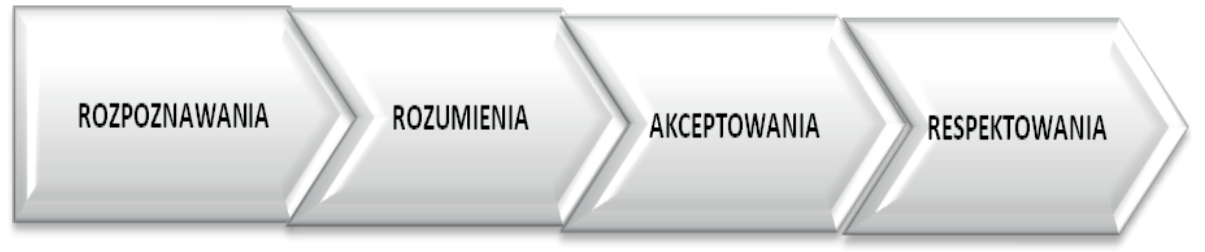

To one na wszystkich etapach kształcenia nadają sens uczniowskiej transgresji w przestrzeni edukacyjnej i edukowanej, pozwalają na transformację tak zwanego wymiaru przedmiotu w pryzmat uczniowskiej podmiotowości.

W literaturze przedmiotu można wyróżnić dwa dominujące podejścia wobec zagadnienia wartości tożsamości nauczyciela w przestrzeni edukacyjnej - podejście fenomenologiczne i poznawcze. Ujęcie fenomenologiczne akcentuje rozwój społeczny, zawodowy i drogę awansu zawodowego, jako wymiar sukcesu pedagogicznego, osiągnięć edukacyjnych uczniów. Natomiast podejście traktujące nauczyciela jako źródło autoedukacji dla siebie samego i wzorca dla innych jest pojęciem poznawczym, ponieważ jest elementem dopingującym do stale obecnej w edukacji twórczości i innowacji, jest źródłem ewaluacji etycznej i hermeneutycznej "prowadzających" to transgresji najważniejszych aspektów życia i rozwoju na zasadach ambiwalencji zrównoważonej Transcedentaliów i Uniwersaliów.

Moment rozumienia siebie, autorefleksji w wymiarze autoanalizy i samooceny to podstawowe paradygmaty budujące i stanowiące autorytet nauczyciela. Decydują o sukcesie pedagogicznym nauczyciela, warunkują kompetencje, relacje z uczniem, umiejętność diagnozowania i ewaluacji oraz aktywność dydaktyczną, wychowawczą i dyscyplinarną. Budowanie autorytetu nauczyciela to proces wieloetapowy, wielowątkowy, utożsamiany z osiąganiem wzorca idealnego nauczyciela i oczywiste jest, że podlega transgresji obyczajowo-kulturowej w niektórych środowiskach społecznych. $\mathrm{Na}$ wszystkich etapach awansu zawodowego każdy współczesny nauczyciel będzie poszukiwać odpowiedzi na najważniejsze dla niego aspekty nauczania, kształcenia i pedagogicznej refleksji, w której (jego) autorytet wychowawczy w sposób mądry wyprzedzałby czas ucznia, a wyznaczane cele sobie $i$ wychowankom nauczyciel mógłby ujmować w strukture "tego, co powinno być”. Ale, czy "pień oświeceniowy" może być wspólny dla ucznia i nauczyciela? Czy edukacyjne przestrzenie nauczycielskie i uczniowskie mogą być inkluzywne? 
Łatwość wpływu na dzieci, ich ontologicznie uwarunkowana podatność na wpływy, zagrożenia patologicznymi wymiarami społecznej obecności wręcz redagują u nauczycieli nakaz, powinność przykładania większej wagi do autorytetów, z jakimi stykają się dzieci. Wyniki wielu badań pedagogicznych odsłaniają obecność złożonych zależności pedagogicznych, socjologicznych, psychologicznych i kulturowych, warunkujących wymiar autorytetu wychowawczego. Zaledwie od kilku lat $\mathrm{w}$ publikacjach pedagogicznych obecna jest jedna z nich: Dorosty jest nauczycielem dla dziecka - dziecko jest nauczycielem dla dorosłego, gdyż do tej pory jakość kształcenia i poziom dyskusji na jej temat był zarezerwowany dla wykształconych pedagogicznych środowisk akademickich. Niestety, coraz częściej społecznie jest zauważalne medialne i praktyczne angażowanie się społeczności uczniowskich (manifestacje, heppeningi, protest itp.), dowodzące społecznej dojrzałości młodego pokolenia.

Reformatorzy oświaty nie mogli przewidzieć wielu nowych zjawisk pedagogicznych, choćby takiego, że autory tet nauczyciela - wychowawcy zmienia swój aksjologiczny "kapitał reputacyjny", nie zawsze potrafiący obronić, wzmocnić, ugruntować pozycję nauczyciela w nowych sytuacjach edukacyjnych i społecznych, a władza utożsamiana $z$ autorytetem to forma i metoda, narzędzie wykonawcze, które także zaczyna ewaluować i destynować treści przedmiotu i podmiotu.

Obecnie jesteśmy świadkami ogólnonarodowej dyskusji pedagogów, socjologów, psychologów i dziennikarzy zaniepokojonych dokonującą się ewaluacją paradygmatu wychowawczego, edukacyjnego i tego najważniejszego pedagogicznego. Idea nadejścia czasu tofflerowskiej cywilizacji "trzeciej fali" ${ }^{8}$ - powstawania społeczeństw informatycznych, a w konsekwencji obecność określonych przemian społeczno-kulturowych - budzą obawy o przyszłość "prawdziwej edukacji”, kształtującej najważniejsze sfery społecznej kulturowości. Bogactwo idei i koncepcji na urządzanie siebie i świata jest współzależne od potencjału zasobów ludzkiego kapitału, a więc od aksjologicznej wartości wiedzy edukacyjnej9. Czy refleksja współczesnej pedagogiki ma szansę wypracowania w edukacji rzeczywistej obecności procesów językowych, metajęzykowych i poznawczych u nauczyciela, kształtującego wartość społeczną w dynamicznie kulturowo przeobrażanej tradycji? B. Suchodolski podkreślał, że człowiek nie jest wcale taki, jakim jest - ale takim, jakim się sta$\mathrm{je}^{10}$. Istotą pedagogiki nie są poznawcze struktury wiedzy empirycznej o czło-

8 A. Toffler, H. Toffler, Budowa nowej cywilizacji. Polityka trzeciej fali, przekł J. Łoziński, Poznań 1996.

${ }_{9}$ K. Denek, Aksjologiczne aspekty edukacji szkolnej, Toruń 2000.

${ }^{10}$ B. Suchodolski, Twórczość - rzeczywistość, nadzieje, wattpliwości, [w:] Wychowanie i strategia życia, Warszawa 1983. 
wieku, ale dostrzeganie i wrażliwość na dokonujące się w nim, i obok niego, procesy nieustannego stawania się, tak bardzo tożsame z ideą przywództwa i przewodnictwa edukacyjnego.

Każda idea ma swój moment zaprzeczenia, przyczyniający się od powstania nowych wzorców, ideałów, norm, standardów. Dla pedagogicznej aksjologii i teleologii przemiany te są restrukturyzacją pedagogicznej rzeczywistości $\mathrm{w}$ spektrum paradygmatu podmiotowości, akcentowaniem treści słusznych, innych, własnych, wyróżniających się. To pedagogiczna, zróżnicowana wartość paradygmatu, rozumianego jako model uprawianych badań, wzorzec postępowania badawczego, czy teoretyczny model nauki ${ }^{11}$, upoważnia coraz częściej środowisko pedagogiczne do stosowania go w celach jeszcze kilka lat wstecz zupełnie niepostrzeganych. Upowszechnienie kształcenia online może zawarunkować obecność panopticum „lustrzanych wirtualnych sześcianów", luster jedynie nauczających i promujących społecznie promowane (i jedynie słuszne - sic!) atrybuty wizerunku zewnętrznego i ministerialnie propagowany homo pedagogus. Nauczanie online może niezauważalnie aktywować entropię nauczycielską, uczniowską i rodzicielską... niestety, nie kształcącą kreatywność intelektualno-kulturową.

Podstawy współczesnych idei wychowania, wyznaczające nowe (ale czy odmienne?) paradygmaty celów, treści i metod kształcenia oraz wychowania określają nowy kierunek reform edukacyjnych, w których rola i zadania wyznaczane nauczycielowi obejmują coraz więcej przestrzeni edukacyjnych i edukowanych. Współczesne systemy nauczania i wychowania coraz bardziej świadomie akcentują wieloaspektowość, wielopoziomowość osoby nauczyciela oraz zróżnicowanie edukacyjnych pól przestrzennych w wymiarze merytorycznym i metodycznym. Polifonia pedeutologiczna dotyczy jego tożsamości podmiotowej, kryteriów oceniania, wyznaczania standardów edukacyjnych. Dotyczy edukacyjnych zmian rangi nauczycielskich przestrzeni wertykalnych $i$ horyzontalnych, relacji szkolnych wyznaczanych nowymi kryteriami, utożsamianych z otwarciem, ekspansją, wolnościa, podatnych na metaforyczność ujećc. To nauczyciel przede wszystkim o humanistycznej postawie,

współcześnie konfrontowany z rozszerzonym, planetarnym wymiarem dostępnego świata, z różnorodnością zjawisk kultury, których znaczenie może być wzbogacające pod warunkiem zaistnienia sprzyjających sytuacji edukacyjnych ${ }^{12}$.

Pragmatyka pedeutologiczna i pedagogiczna, oparte na relacjach interpersonalnych, współcześnie sytuują nauczyciela w sieci różnych powiązań

${ }^{11}$ W. Okoń, Nowy stownik pedagogiczny, Warszawa 2001, s. 282.

${ }_{12}$ I. Wojnar, Edukacja humanistyczna i trzy kreggi tożsamości człowieka, [w:] Uczeń i nowa humanistyka, red. M. Kujawska, Poznań 2000, s. 99. 
ludzkich, których ważną część stanowi podleganie oraz sprawowanie władzy. W przestrzeni edukacyjnej ma postać prawa, obowiązku decydowania, realizacji szeroko rozumianej służby społecznej. W każdej strukturze społecznej, a tym bardziej w środowisku edukacyjnym obowiązuje hierarchiczna struktura odpowiedzialności, wpływu, a więc władzy - zadaniowej, etycznej, merytorycznej i społecznej. W jakim stopniu nauczyciel zawodowo jest prawomocny w realizacji idei i teorii pedagogicznych, współcześnie podlegających transcendencji medialnej, socjologicznej, polityki oświatowej, a nawet rewolucji informatycznej? Czy tradycyjne prawo nauczyciela do decydowania o uczniu, za ucznia, dla ucznia może być postrzegane i utożsamiane z przywództwem edukacyjnym, jeśli w powszechnym, społecznym przekonaniu jest ono kojarzone z władzą? Czy współcześnie nie powinny dokonywać się przeobrażenia nauczycielskiego wpływu w całym spektrum pedagogiczno-psychologicznym?

Współczesną perspektywę rozważań przywództwa edukacyjnego stanowić powinny zróżnicowane rodzaje aktywności edukacyjnej, to jest:

1) przygotowanie młodych pokoleń do uczestnictwa w życiu społecznym, ekonomicznym i kulturalnym jako strategia edukacyjna zorientowana na sukces dla wielu współczesnych nauczycieli znana i oczywista; to system kształcenia przygotowujący ludzi do obrony i rekonstrukcji współczesnej cywilizacji, do umiejętności kierowania swoim dalszym rozwojem; to wychowanie obecne $\mathrm{w}$ przestrzeni edukacyjnej najczęściej obejmujące obszary ludzkiego życia, które odpowiadają autonomicznym dziedzinom wiedzy, bowiem selekcjonują aspekty ludzkiej osobowości;

2) kształtowanie u młodych ludzi ich rozwoju w celu ukierunkowania na szczęście, jako hedonistyczna strategia edukacyjna zorientowana na wybór wartości; to system kształcenia pragnący udzielać młodym ludziom pomocy i wsparcia, by mogli tworzyć i realizować wartości; to edukacja obejmująca wychowaniem najróżniejsze obszary życiowe dziecka związane z poznawaniem rzeczywistości, to jest świata przyrody, społeczeństwa, kultury; to także działalność w świecie wyrażana ludzką pracą, twórczością, społeczną obecnością, a więc społecznym uczestnictwem, której „skutkiem” będzie rozwój osobowy widoczny w umiejętnym kierowaniu własnym życiem i dostrzeganiem $w$ treściach kształcenia wartości autonomicznych i indywidualnych dla własnej osoby ${ }^{13}$.

Przywództwo edukacyjne, jego aspekt osobowy, pedeutologiczny, kulturowy, wpisujące się w dualizm analityczny (osobowościowy i środowiskowy) osoby i pracy współczesnego nauczyciela, jest zawarte $\mathrm{w}$ wielu współczesnych teoriach przywódczych R.A. Webera, dorobku badań naukowych A. Bi-

\footnotetext{
${ }^{13}$ B. Suchodolski, Wychowanie dla przyszłości, Warszawa 1968.
} 
neta, J.A. Stonera, F.Ch. Wankela, R.W. Griffina, czy filozoficznych refleksjach H.G. Gadamera, E. Levinasa, M. Bubera, czy też ks. J. Tischnera. Przywództwo edukacyjne, zgodnie z poglądami R. Havighursta, zwracającymi uwagę na wynik uczenia się ${ }^{14}, \mathrm{w}$ określeniu zadań rozwojowych uwzględnia tak zwany moment wyuczalności, w którym konkretne zadania lub wymagania dydaktyczno-wychowawcze osiągają w osobie nauczyciela moment gotowości i skupienia uwagi na osobie ucznia, uwzględniającym jego predyspozycje, percepcję i moment asymilacji wiedzy. Na taki pedagogiczny moment dojrzałości zawodowej składają się odpowiednie kompetencje poznawcze, moralne, społeczne i dyspozycje osobiste oraz antycypacja pełnionej roli edukacyjnej przez (i dla) ucznia i społeczności uczniowskiej. Pojęcie zadanie jednoznacznie utożsamia się z działaniem strategicznym, to jest zaplanowanym i kontrolą jego przebiegu. W przypadku procesu wychowawczego strategia powyższa wyklucza przypadkowość i akcentuje poziom koncepcji działania. Osobowość nauczyciela i poczucie odpowiedzialności (określane powołaniem pedagogicznym) to podmiotowe desygnaty w strukturze wychowania. W rozważaniach teoretycznych można edukację warunkować efektywną strategia przywództwa społecznego, aksjologicznego, psychologiczno-pedagogicznego, czy aspektem charyzmy. Natomiast, współczesne realia cywilizacyjne (szczególnie holizm pandemii $2020 \mathrm{roku}$ ), uwarunkowania polityczno-ekonomiczne, eklektyzmy oświatowe zaczynają stawać się fundamentem dla natywizmu pedeutologicznego, agnostycyzmu poznawczego, probabilizmu wychowawczo-opiekuńczego, a nawet uniformizacji deontycznej. Współczesny, pandemiczny kryzys swoim społecznym i ekonomicznym tsunami także potwierdził niezwykłą mądrość i przenikliwość cywilizacyjną Z. Baumana, który już wiele lat temu twierdził, że świat szkoły jest zupełnie inny niż świat jej absolwentów, do którego byli w przeszłości przygotowywani! Zatem, może narracyjną powinnością środowisk akademickich, kształcących nauczycieli, pedagogów i wychowawców, powinny stawać się sytematyczne i coroczne analizy efektywności jakościowej i ilościowej rangi nauczycielskiej, uczniowskiej, metodycznej oraz progresu kultury i wiedzy uczniowskiej? Czy i jak dogłębnie możliwa jest synergia elitaryzmu i egalitaryzmu podmiotowości oraz komercji edukacyjnej? Dlaczego nauczyciele nadal nieskutecznie zapobiegają rozprzestrzenianiu się w społecznościach uczniowskich aktów nacjonalizmu, fundamentalizmu, stygmatyzacji, deprawacji przedmiotwej i osobościowej z tytułu supremacji, na przykład nauczycielskiej, funkcyjnej, statusu lokalnego? Czy współczesne wydarzenia pandemiczne, tak bardzo deregulujące pracę i funkcje środowisk szkolnych, staną się katalizatorami

14 A.C. Ornstein, F.P. Hunkins, Program szkolny, problematyka, przekł. K. Kruszewski, Warszawa 1998, s. 138-139. 
w wymiarze egalitarnym, które wyzwolą niewielkie spekturm aktywności zawodowej i wychowawczej, czy staną się katalizatorami w wymiarze elitarnym, gwarantując edukację prognostyczną, dywergencyjną, afiliacyjną oraz siłę pedagogiki, a nie pedagogikę siły?

\section{BIBLIOGRAFIA}

Aproksymacja - https://sjp.pwn.pl/slowniki/aproksymacja.html, [dostęp: 01.05.2020].

Aronson E., Wilson T.D., Akert R.M. Psychologia społeczna, Zysk i S-ka Wydawnictwo, Poznań 1997.

Denek K., Aksjologiczne aspekty edukacji szkolnej, Wydawnictwo Adam Marszałek, Toruń 2000.

Holt J., Zamiast edukacji. Warunki do uczenia się przez działanie, przekł. D. Konowrocka, Oficyna Wydawnicza Impuls, Kraków 2007.

Kunowski S., Podstawy współczesnej pedagogiki, Wydawnictwo Salezjańskie, Warszawa 1993.

Kwaśniewski K., Tożsamość społeczna i kulturowa, Studia Socjologiczne, 1986, 3.

Melosik Z., Kultura popularna jako czynnik socjalizacji, [w:] Pedagogika. Podręcznik akademicki, tom 2, red. Z. Kwieciński, B. Śliwerski, Wydawnictwo Naukowe PWN, Warszawa 2003.

Okoń W., Nowy słownik pedagogiczny, Wydawnictwo Akademickie Żak, Warszawa 2001.

Ornstein A.C., Hunkins F.P., Program szkolny, problematyka, przekł. K. Kruszewski, Wydawnictwa Szkolne i Pedagogiczne, Warszawa 1998.

Sławiński S., Wychowywać do postuszeństwa, Instytut Wydawniczy PAX, Warszawa 1994.

Suchodolski B., Wychowanie dla przyszłości, Państwowe Wydawnictwo Naukowe, Warszawa 1968.

Suchodolski B., Twórczość - rzeczywistość, nadzieje, wattpliwości, [w:] Wychowanie i strategia życia, Wydawnictwa Szkolne i Pedagogiczne, Warszawa 1983.

Toffler A., Toffler H., Budowa nowej cywilizacji. Polityka trzeciej fali, przekł. J. Łoziński, Zysk i S-ka Wydawnictwo, Poznań 1996.

Wojnar I., Edukacja humanistyczna i trzy kręgi tożsamości człowieka, [w:] Uczeń i nowa humanistyka, red. M. Kujawska, Instytut Historii UAM, Poznań 2000. 